\title{
Design Method for EPS Control System Based on KANSEI Structure
}

\author{
Yumi Saitoh Member (OMRON Corporation, yumi@ari.ncl.omron.co.jp) \\ Hideaki Itoh Non-member (OMRON Corporation, hito@ari.ncl.omron.co.jp) \\ Fuminori Ozaki Non-member (OMRON Corporation) \\ Takenobu Nakamura Non-member (OMRON Corporation, t_nakamura@autos.omron.co.jp) \\ Shigeyasu KawajiＳenior Member (Kumamoto University, kawaji@cs.kumamoto-u.ac.jp)
}

Keywords: electric power steering, KANSEI structure, control system, parameter tuning method

Recently, it has beed identified that a KANSEI engineering plays an important role in functional design developing for realizing highly sophisticated products. However in practical development methods optimized products are designed and the design is by trial and error, which indicates that we depend on the skill set of experts. In this paper, we discuss the case of an automobile electric power steering (EPS) for which such a functional design is required. First, the KANSEI structure is defined on the basis of the steering feeling of an experienced driver, and an EPS control design based on this KANSEI structure is proposed. Then, the EPS control parameters are adjusted in accordance with the KANSEI index. Finally, after an assessment of the experimental results obtained from the driver, the effectiveness of the proposed design method is verified.

When tuning the EPS control system, steering feeling evaluation and adjustment of the motor control parameters are repeated so that the sttering feeling is similar to that experienced with a hydraulic power steering system. Since only an experienced driver can evaluate the steering feeling, we depend on the skill set of these drivers to confirm the validity of our method. Moreover, because the relationship between the evaluation of the steering feeling and the motor control parameters have not been clarified, parameter adjustment is trial and error.

We extracted the KANSEI index components after a discussion with the driver and verified the correlation between each other of the KANSEI indices. On the basis of the KANSEI structure obtained from this method, we evaluated the KANSEI indices for the set of estimated parameters. Figure 1 shows the KANSEI structure

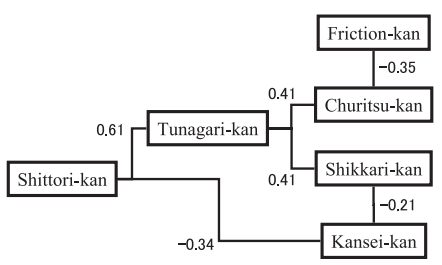

Fig. 1. KANSEI Structure determined from the evaluation experiments.

The control system designed by using the KANSEI structure obtained using the proposed method is shown in Fig. 2. A KANSEI index identifier is constructed on the basis of the results obtaioned for experiments conducted on a support vector machine and by using steering torque and motor rotation frequency crresponding to each KANSEI index. By using the KANSEI index identifier, the KANSEI index related to the driver's steering feeling is distinguished from that related to the combination of the steering torque and the motor rotation frequency.

The results of the evaluation perfomed in the range of car speed $20-40 \mathrm{~km} / \mathrm{h}$ are shown in Fig. 3. The figure shows that the steering feeling experienced with the proposed EPS control sytem is better with than that experienced with the conventional EPS control systems.

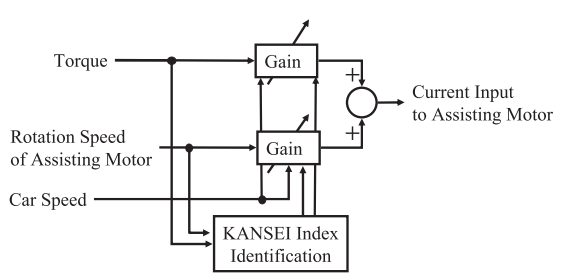

Fig. 2. Structure of Controller

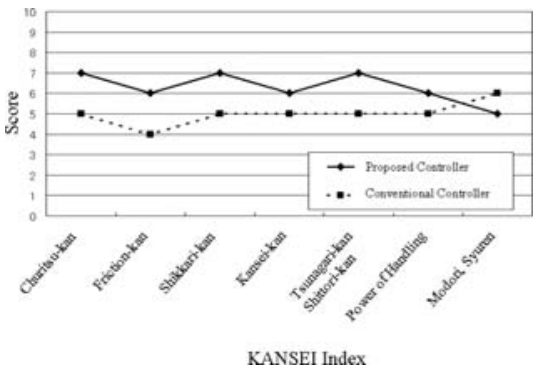

Fig. 3. Comparision in the middle speed 


\section{感性構造に基づくEPS 制御系のパラメータ調整}

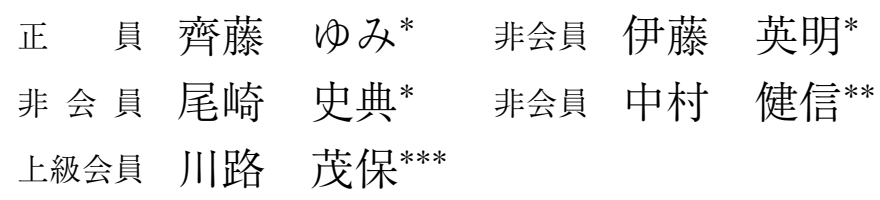

\section{Design Method for EPS Control System Based on KANSEI Structure}

Yumi Saitoh*, Member, Hideaki Itoh*, Non-member, Fuminori Ozaki*, Non-member, Takenobu Nakamura**, Non-member, Shigeyasu Kawaji***, Senior Member

Recently, it has been identified that a KANSEI engineering plays an important role in functional design developing for realizing highly sophisticated products. However, in practical development methods, we design products and optimise the design trial and error, which indecates that we depend on the skill set of experts.

In this paper, we focus on an automobile electric power steering (EPS) for which a functional design is required. First, the KANSEI structure is determined on the basis of the steering feeling of an experienced driver, and an EPS control design based on this KANSEI structure is proposed. Then, the EPS control parameters are adjusted in accordance with the KANSEI index. Finally, by assessing the experimental results obtained from the driver, the effectiveness of the proposed design method is verified.

キーワード : 電動パワーステアリング, 感性構造, 制御系, パラメータ調整

Keywords: electric power steering, KANSEI structure, control system, parameter tuning method

\section{1. はじめに}

現在，モノづくりカの強化に向けた取り組みの中で，グ ローバルでの優位性を保つために，感性価值の向上が揭げ られている(1)。作り手が，顧客の感動，共感を意識し，顧 客と感性価值を共創可能な製品を提供することにより，製 品の高付加価值化が実現できるとの仮説にもとづいている。 従来，製品は多様な機能の組み合わせで多品種の商品を顧 客に提供し, 顧客が自分に必要な機能を選択することで, 商 品価值が評価されてきた。従って，顧客の感性を考慮した 機能設計が求められる製品の場合, 製品の機能の組み合わ せは顧客の評価に合わせて試行錯誤的に提供されることに

\footnotetext{
*オムロン (株) コアテクノロジーセンター

干 619-0283 木津川市木津川台 9-1

Core Techonology Center, OMRON Corporation

9-1, Kidugawadai, Kidugawa 619-0283

**オムロン (株) オートモーティブエレクトロニックコンポーネン ツカンパニー

厂 485-0802 小牧市大草年上坂 6368

AEC Company, OMRON Corporation

6368, Nenjozaka, Okusa, Komaki 485-0802

*** 熊本大学 大学院 自然科学研究科

干 860-8555 熊本市黒髪 2-39-1

Graduate School of Science and Technokogy, Kumamoto University

2-39-1, Kurokami, Kumamoto 860-8555
}

なり，効率的とは言い難い。

現在は匠と呼ばれる一握りの熟練者による設計が中心で ある。熟練者は, 顧客の感性価值を自身で解釈し, デザイ ンに落とし込むことで, 製品の感性価值を向上させている。 このように, 感性価值に着目してデザインすることは, 有 効であると考えられるが, 感性価值に着目した設計方法は 確立されていない。

感性価值向上が求められる一般消費者に身近な例として 自動車がある。外観的な要素の感性価值は, 購入者の主要 な価值基準である一方で, 駆動特性, 制動性能, 操縦安定性 など車の性能についても購入者の感性に合う特性が求めら れる。これらの特性の中で, 操縦安定性に係わる自動車の構 成要素として, 電動パワーステアリング (Electronic Power Steering, EPS) (2) がある。

燃費の向上，保守の容易さ，自動運転を最終目的とする 高度精度化の実現に向けて, 従来の油圧に代わりモー夕に よるアシスト方式が一般的になりつつある。その際, ユー ザが感じる従来との違和感を小さくし, 油圧アシスト方式 と同等の運転感覚を感性価值として生み出すための EPS 制 御技術が重要となる。ユーザが感じる運転感覚とは, ハン ドル操作の重さ, 軽さを始めとし, 一般的には意識されて いない感覚などを含んでいる。こうした総合的なステアリ ングの運転感覚を操舵感と呼んでいる。 
油圧方式と同等の操舵感を生み出すためには, 長年経験 を積んで, 操舵感の評価が可能である評価ドライバが, 運 転, 評価, 及びモータの制御パラメータの調整を繰り返す ことで実現している。その結果, EPS の感性価值向上は試 行錯誤的なアプローチとなっている。

そこで，本論文では EPS を対象に，EPS 制御系を調整す る熟練評価ドライバの操舵感に関わる感性構造を明らかに し, 獲得した感性構造を利用した制御系を提案する。さら に, 従来型 EPS 制御系と提案型 EPS 制御系の比較評価実 験を行い，本手法の有効性を確認する。

\section{2. 問題設定}

本章では, EPS 制御系および自動車業界における EPS の 製品搭載決定までの流れを概説し, 現状の EPS 制御系およ び調整が抱える問題点を考察する。

〈2・1〉 EPS 制御系ＥPSは，ドライバからハンドル へ入力される操舵トルクと運転状況や環境にしたがって, ド ライバの操舵をアシストするトルクを発生させる。その代 表的な構成であるコラムアシスト型 EPS を Fig. 1 に示す。 電子制御ユニット (Electric Control Unit, ECU) と呼ばれ る EPS 制御系がドライバからハンドルに伝えられる操舵卜 ルクなどの情報にもとづき，アシストモータへ電流を印加 する。

アシストモータへの電流指令值は, Fig. 2 に示すように, 操舵トルクに車速に従った非線形ゲインを乗じる比例制御, 操舵卜ルク微分值およびアシストモータの回転速度に車速 に従ったゲインを乗じる微分制御により算出されている。

現在の EPS ではこのような非線形 PD 制御系 ${ }^{(3) \sim(5)}$ が主 流となっており, 操舵トルクへの車速による比例制御部の 例を Fig. 3 に示す。ドライバが入力した操舵トルクに対す る非線形ゲインを車速ごとのテーブルとして持ち，テーブ ル間のトルク及び車速では補間を行い，比例ゲインを算出 し，アシストモータへの電流指令值が生成されている。

$\langle\mathbf{2} \cdot 2\rangle$ EPS の実車搭載 一般に自動車メーカからの 仕様をもとに，ステアリングメーカが EPS システムを設 計・開発し, 自動車メーカへ提供している。EPS のハード ウエアおよびその制御を実行する ECUについては，それ ぞれ仕様化され, 自動車メーカの検収条件が存在する。そ の際, 制御系パラメータの調整により実現されるEPS の操 舵感に関しては, 自動車メーカの評価ドライバによって評 価（感性評価）が行われるため, 仕様化が困難である。そ のため, 自動車メーカにおける承認がおり, 量産品として 提供されるまでに，ステアリングメーカの評価ドライバが 評価・調整し, 自動車メーカの評価を受けるという手順が 繰り返される。また, 自動車メーカごとに, 更にはライン ナップしている自動車ごとに設定したい操舵感が異るため, 車種ごとの EPS の感性評価, 制御系パラメー夕調整が必要 である。

〈2·3 EPS が抱える問題点＼cjkstart前節で述べた評価にお いて, 自動車メーカの評価ドライバによる評価が良好でな

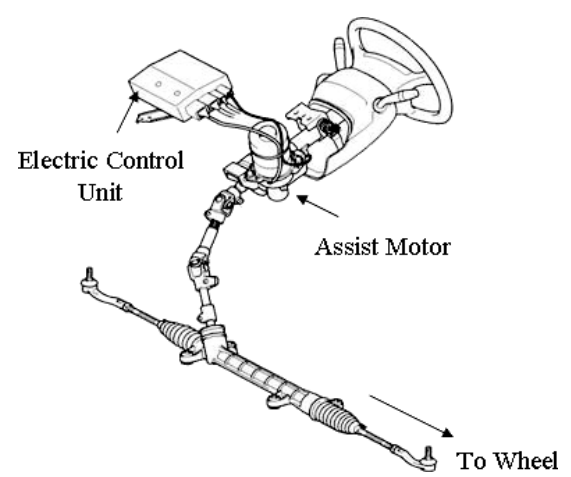

Fig. 1. Structure of EPS

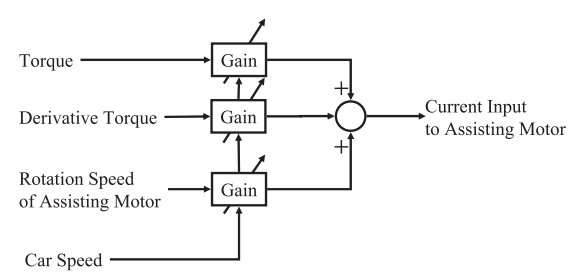

Fig. 2. Current Input to Assist Motor

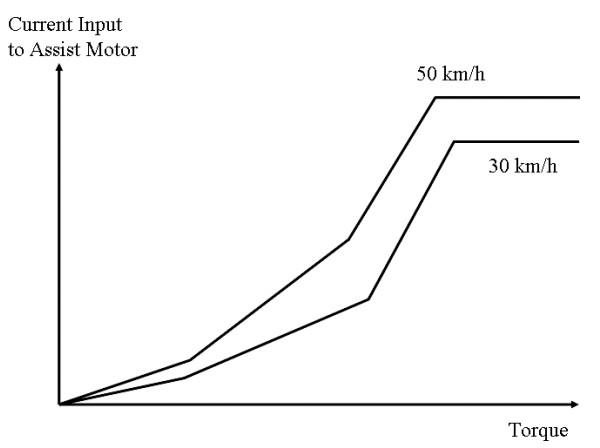

Fig. 3. Example of Proportional Control for Torque

い場合は，その評価結果をもとにステアリングメーカの評価 ドライバが制御系パラメータの調整を繰り返すこととなる。 この過程で, ステアリングメーカと自動車メーカの評価ド ライバ間では, 評価項目と評価結果の共有が行われている。 しかし, 評価結果の共有と課題の認識が行われた後に, ス テアリングメーカ側で調整を再度実施する場合には, 課題 に対する調整の具体的な指針がなく, 試行錯誤的となって いる。これは, 非線形 PD 制御系の採用により, 調整対象 となるパラメータ数が多いことから, 評価ドライバの熟練 者の感覚として内在している感性評価と制御系パラメータ を直接的に関係づけることが困難であることに起因してい る。感性評価に対応する主要因の制御系パラメー夕を顕在 化させることで, 調整の短期間化につながると考えられる。

\section{3. 熟練者の感性評価構造}

前章での EPS 制御系パラメー夕調整の問題を克服するた めには, 熟練評価ドライバの感性評価における感性指標と 制御系パラメータの関連性を抽出することが必要である。 そのため, ドライバに内在している感性評価に関する情報 を獲得し, 感性評価項目の指標化と制御パラメータとの関 


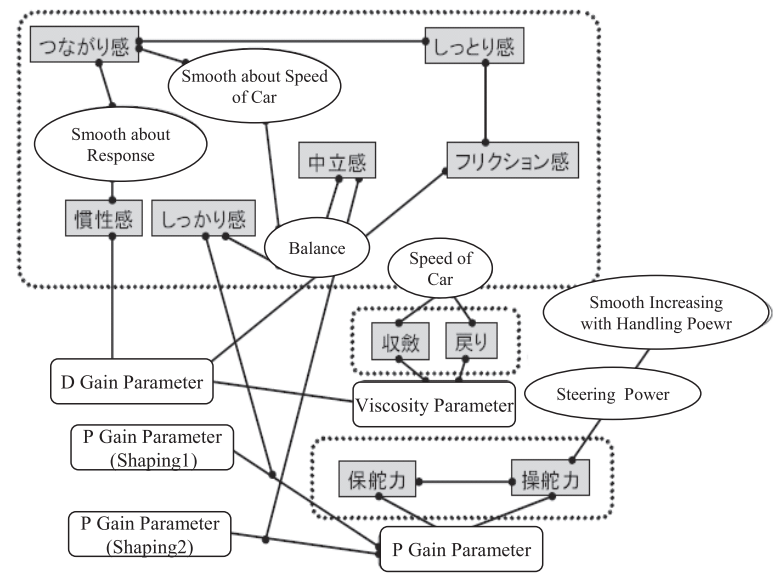

Fig. 4. Assumption of KANSEI Structure

連づけを実現する。これにより，制御系パラメー夕調整を 行う際に, 調整対象となるパラメータの特定や, 調整の手 順化，調整範囲を決定できると考える。更には，制御系の 構成を見直すための有益な情報ともなりうる。これに対し， 著者らの先行研究において, 感性情報の抽出や獲得手法と 熟練評価ドライバの感性構造を明らかにした ${ }^{(6)}$ 。本章では その概要を示す。

$\langle\mathbf{3} \cdot 1\rangle$ 感性情報の抽出・獲得手法 熟練評価ドライ バに内在する感性は，長年の調整，評価経験がなければ一 般には理解できないものである。そこで，熟練評価ドライ バに内在する感性の構造を明らかにするために，感性の構 成要素抽出と関連性についての仮説を設けて, 実車実験と 評価を行い，制御系パラメータの調整に活用出来る構造を 得た。

$\langle\mathbf{3} \cdot \mathbf{1} \cdot \mathbf{1}\rangle$ 感性の構成要素抽出と仮説 まず，評価グ リッド法と呼ばれるインタビュー手法(7)を用いることで感 性の構成要素を抽出する。インタビューは, 熟練評価ドラ イバが過去に評価したことがある具体的な車種を起点とし て行った。その結果を Fig. 4 に示す。

評価ドライバの感性評価の構造は, 特徵的な操舵感覚 (四 角）と各操舵感の具体的説明 (楕円), 及び EPS の制御パラ メータ (角丸の四角) をノードとするネットワーク関係と して得られた。また, Fig. 4 に示す操舵感覚は, 評価ドライ バの操舵感を過不足なく言語化したという意味から「感性 指標」と名付けた。Fig. 4 から, 感性指標は, 図中の 3 つの 破線囲みの独立した群に分離される。これは，異なる群に 属する感性指標が直接的，及び操舵感の説明のみを介して 結合していないことによる。評価ドライバの意見から，操 舵感の品質評価に相当するのは，最上部の破線囲みである ことがわかった。（他の 2 群は，操舵感の個性を示すための 要素となる。）本論文では, 操舵感の品質評価に着目し, 制 御系パラメータとの関係性の検討を行う。

$\langle\mathbf{3 \cdot 1 \cdot 2 \rangle}$ 定量分析による感性構造決定 インタビュー によって得られた感性構造ネットワークから，制御系パラ メータを介した感性指標間の関係性を仮説し，制御系パラ

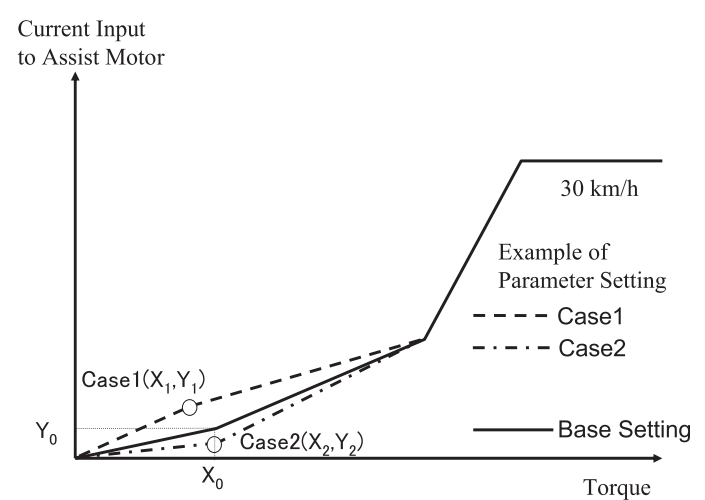

Fig. 5. Torque-Current Table

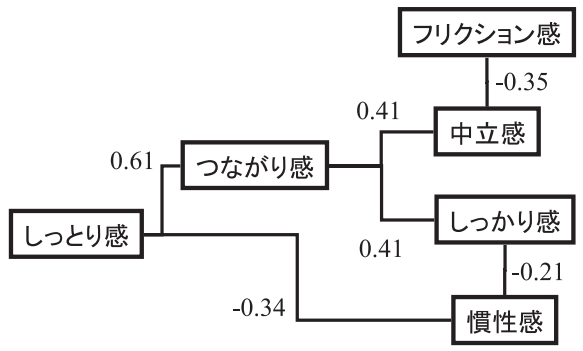

Fig. 6. KANSEI Structure

メータの調整に活用可能な構造を得るべく，感性指標間の 関係性を実車実験により定量的分析を行った。具体的には, 非線形 $\mathrm{P}$ ゲインであるトルクー電流曲線のパラメータ, 非 線形微分ゲインのパラメータ，粘性ゲインのパラメータの 各制御パラメータに対して，異なる設定值を持つ 40 組の パラメータセットを準備する。準備したパラメータセット に対して, 感性指標ごとに感性評価を行った。トルクー電流 曲線に対する変更パラメータの一例を Fig. 5 に示す。トル クー電流曲線については, 第一折れ点の影響が最も大きいた め第一折れ点の座標をパラメータとして保持し，パラメー 夕の移動に合わせて曲線を変形させた。

また，操舵感の調整については， $30 \mathrm{~km} / \mathrm{h}$ での走行時の 調整が最も困難であるという熟練評価ドライバの経験的知 見から，30 km/h を中心とした低速，中速領域に着目した。 なお車両は一般の小型軽自動車を対象にして行った。

同一のパラメータセットに対して運転し，各感性指標ご とに 0 点を中心として， -2 点 (劣悪) から+2 点（良好） で評価を行った。評価結果のデー夕を用いて共分散構造分 析 ${ }^{(8)}$ を行い, Fig. 6 の感性構造を得た。Fig. 6 の感性指標を 結ぶ線上の数值は，感性指標間の影響の度合い（重回帰分 析における変化行き係数にあたる）を示す。図中，中立感 (操舵字の中立点の明確さ) とフリクション感（舵角ゼロ近 辺でのなめらかさ）を結ぶ線上の負の值は，一方の感覚を 良好にすると, 他方の感覚が劣化するというトレードオフ の関係にあることを示している。また, Fig.6において, 右 側の項目ほど物理量に近い評価項目となっており, 調整の 際には下位の評価項目から順に調整することで全体評価で ある「しっとり感」を向上出来ることがわかる。 


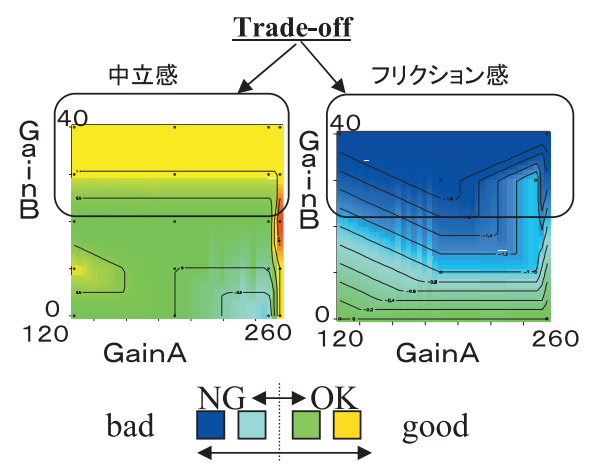

Fig. 7. Trade-off between Churitsu-kan and Frictionkan

$\langle\mathbf{3} \cdot \mathbf{1} \cdot \mathbf{3}\rangle$ 制御系への課題 前節で, 感性構造の定量評 価からトレードオフ関係を示した。これは，制御パラメー 夕調整の観点から, Fig. 7 に示すような同一ゲインにおけ る各感性指標の感性評価結果を描くことによってもわかる。 すなわち, 中立感が良好なゲイン領域では, フリクション 感の評価が悪くなるというトレードオフ関係が現れる。同 様のトレードオフ関係は, しっかり感と慣性感にも存在す る。また，実車での評価の過程において，ドライバが特定 の感性指標に着目して運転, 評価する場合, 感性指標によっ て操舵の速度や舵角範囲といった操舵の特徵が異なる状況 が観察された。上記の観察より，感性評価を向上させるた めには, 操舵の特徴を瞬時に判断し, トレードオフを解消 できる制御系が必要であることがわかった。

\section{4. 感性構造に基づく EPS 制御系}

前章で示した感性指標間のトレードオフを解消するため に，以下の 2 つの戦略を立てた。

・運転中の評価ドライバがどの感性指標に対して最も注 目しているかを，EPS の物理的な情報から判断する

・運転中の評価ドライバが注目している感性指標に対し て, 評価ドライバが良好であると判断する制御パラメー 夕を設定する

これらの戦略を具体化することで, EPS 制御系はドライバ が着目する感性指標に沿ったアシストモータへの電流指令 值を出力し，全ての感性指標を満足できると考えられる。 そこで, Fig. 8 に示す構造のコントローラを構成すること とする。

$\langle\mathbf{4} \cdot \mathbf{1}\rangle$ 感性指標の識別＼cjkstart感性指標の識別には, 評価ド ライバの感性指標ごとの操舵データを利用する。操舵デー タとして取得可能な情報は, EPS のハンドル部に設置され ているトルクセンサから得られるステアリングトルクと， 電流波形から得られるアシストモータの回転数推定值であ る。トルクセンサからは, $-5 \sim+5[\mathrm{Nm}]$ のレンジでステア リングトルクが計測され，アシストモータ回転数推定值は, -1000〜+1000[rpm] のレンジで取得される。

評価ドライバは, 各々の感性指標を評価する場合，ある 一定パターンの操舵を繰り返して評価を行っていることか

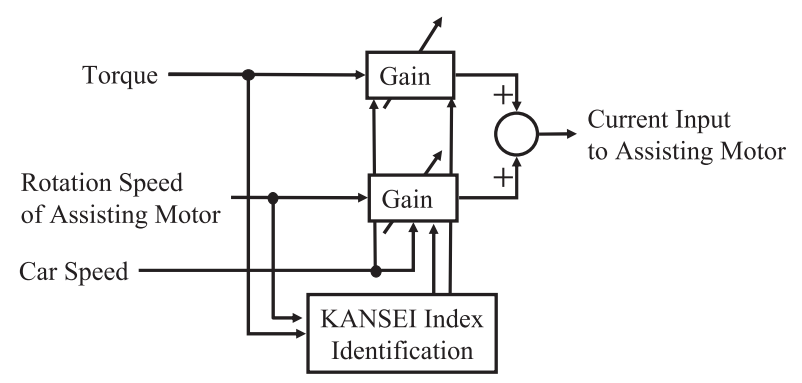

Fig. 8. Structure of Controller

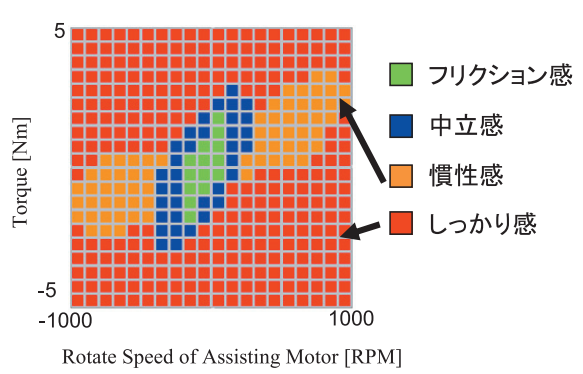

Fig. 9. Map for KANSEI Index Identification

ら, 感性指標ごとの評価運転の条件別に, ステアリングト ルクとアシストモータ回転数推定值を取得した。各感性指 標の評価に効果的な操舵パターンを, 評価ドライバが長期 間の試行錯誤的な運転経験により得ていることから, 感性 指標ごとの評価時の操舵データが最も感性指標ごとの操舵 特性を表現していると考えたためである。

この方法によって収集したデータを, 感性指標ごとに同 一サンプル数に揃え, サポートベクターマシン (Support Vector Machine, SVM) ${ }^{(9)}$ による機械学習を行うことで, ス テアリングトルクとモータ回転数推定值の組み合わせにお いて最も出現確率が高い感性指標を, 評価ドライバが感じ る感性指標と設定した。なお，実装上の都合から，感性指 標識別は, 各入力の計測範囲を 20 分割した分解能 (ステア リングトルクは, $0.5[\mathrm{Nm}]$, モータ回転数は $50[\mathrm{rpm}])$ とし た。本識別器の構成手段を用いて得られた結果を，ステア リングトルクとアシストモータ回転数推定值からマップと して表現し, 運転中の評価ドライバが感じる感性指標の特 定を行う。Fig. 9 に得られた感性指標識別に利用するマッ プを示す。

〈4・2〉 制御系設計 前節で示した感性指標を識別す るマップを利用し, 識別結果に従って感性指標に対応した 制御パラメータ設定が可能なコントローラを設計する。コ ントローラは, 感性指標ごとの制御パラメータをテーブル として保持しており，識別結果に沿った制御パラメータ変 更を約 $1 \mathrm{msec}$ 周期で行う。ここでの制御パラメータとは, 車速ごとに設定される以下の 3 パラメータである。

・操舵トルクー電流曲線（比例ゲイン）

・操舵トルク微分值に対するゲイン（微分ゲイン）

・モータ回転数推定值に対するゲイン（粘性ゲイン） 


\section{5. 感性評価結果}

〈5・1〉 パラメータ調整まず，トレードオフ関係にあ る感性指標間に対して加えた調整を示す。具体的には，以 下の調整を行った。

（1）各感性指標が良好となるパラメー夕を探索

(a) 評価ドライバが，1つの感性指標に着目して，運 転，評価を行う。

(b) 評価ドライバの評価結果に基づき，コントローラ の制御パラメータを試行錯誤的に調整する。

(c) (a), (b) を繰り返す。

（2）トレードオフ関係にある感性指標のつながりを重 視しての調整

(a) 調整する感性指標を 2 つ選択する。

(b) コントローラの感性指標識別による感性指標の切 替えタイミングに着目して，ゲイン調整を行う。

(c) (a)，(b) を感性指標の組み合わせ毎に行う。

（1）は各感性指標が良好になる制御パラメータを求める ものである。ここでの“良好である”，“良好でない”の評価 は，評価ドライバによる評価で決定することとした。実験 では，約 1〜2 時間程度をかけることで，評価ドライバが “良好である”と評価する制御パラメータ探索が終了した。

各感性指標にとって，感性評価が良好な制御パラメー夕 に設定すると，感性指標間の制御パラメータ值の差異が大 きくなる。特にトレードオフの関係にある, 中立感とフリ クション感, しっかり感と慣性感に関しては, 制御パラメー 夕值の差が大きい。コントローラの感性指標識別をもとに 制御パラメータを切替る際, EPS の応答特性が大きく変化 し，評価ドライバに違和感を与えてしまう。そこで，（2） において，感性指標ごとの性能評価の劣化が小さい範囲で, 制御パラメータ值の差が小さくなるように調整を加えてい くこととした。

以上の手順に則った調整を行うことで，感性構造を利用 して, 感性指標ごとの調整・評価データから, 感性指標を特 定し, 制御パラメータを切替る制御系の調整が可能となっ た。その結果，操舵感の向上と調整期間短縮が可能となっ た。実績值として，従来，1 ケ月以上必要としていたのに 対し，本調整手順により，1つの車速領域に対して約 2 日 間，全車速領域に対しては約 2 週間で調整を終えることが できた。さらに，本手法による調整を用いた場合には，制 御パラメータの変更と, 操舵感への影響が, 調整時のデー 夕を用いて視覚化できるため, 検収時の微調整にも対応が 可能となった。

$\langle\mathbf{5} \cdot \mathbf{2}\rangle$ 感性評価結果と考察 4 章で提案したコント ローラ構造および前節の調整で得られた制御パラメータを 設定した EPS 制御系の感性評価を行った。低速領域である 0-20 km/h，中速領域である 20-40 km/h で評価した結果を Fig. 10 と Fig. 11 に示す。感性評価は, 全感性指標に対し て行い，本論文の制御系で性能向上を狙った品質性能に相 当する 6 つの感性指標に対する評価結果を一点鎖線囲みで

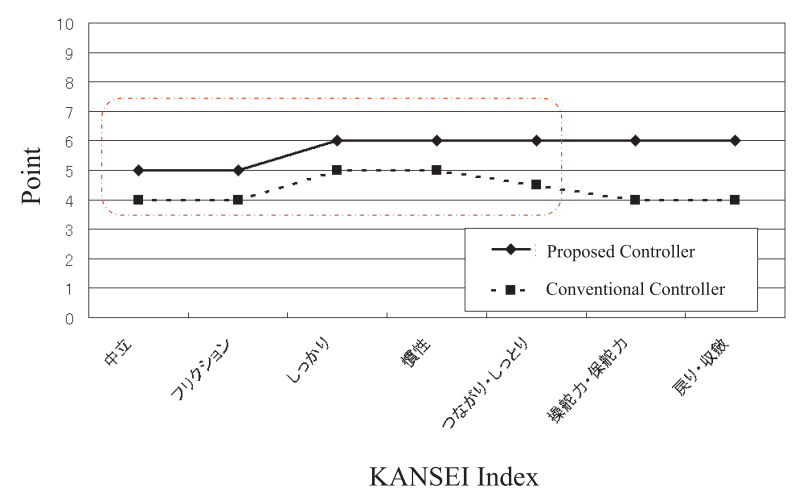

Fig. 10. Comparision in the low speed region

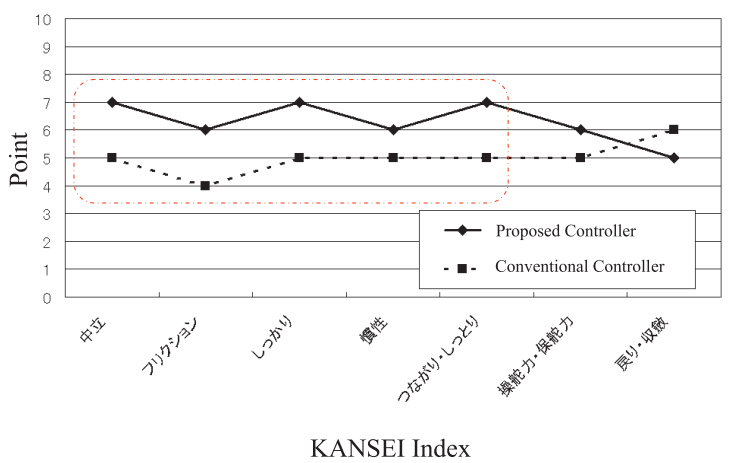

Fig. 11. Comparision in the middle speed region

示している。評価は評価ドライバが行い，感性指標ごとに $0 〜 10$ 点の間で得点をつけた。評価の得点は, 評価ドライ バに絶対的な評価基準があるものではなく, 従来型と比較 することでつけられたものである。

Fig. 10 と Fig. 11 の結果より，目的とした品質性能に対 応する 6 つの感性指標で量産品よりも向上していることが わかる。調整時に着目した中立感，フリクション感，しっ かり感, 慣性感の操舵感がそれぞれ向上し, その結果, 感 性構造上，上位概念にあたるしっとり感，つながり感の向 上に繋がっているものと思われる。低速領域と中速領域に おいて向上した点数の差異は, 低速領域が中速領域と比較 して, 制御パラメータで調整可能な範囲が限定的であるこ とによる。このことは, 評価ドライバが経験的に，低速に なるほど各感性指標の評価を向上させる調整が困難になる という知見からも，妥当な結果であると考えられる。

\section{6. おわりに}

本論文では，自動車の EPS を対象に以下の課題に取り組 んだ。

- EPS 制御系パラメータ調整の問題点の明確化

- 感性指標の抽出と構造化

・評価ドライバが着目する感性指標に沿って制御パラメー 夕変更を行う制御系提案

・各感性指標の制御パラメータ調整

EPS 制御系パラメータ調整の問題点の明確化では，熟練 評価ドライバ間で共有された操舵感に対する課題に対し, 
調整の具体的な指針が存在しないことを問題として捉えた。 感性指標の抽出と構造化では, 評価ドライバが持つ操舵 感と呼ばれる総合的な感性を細分化し，感性構造の妥当性 を評価した結果を分析した。感性構造㧍よび調整パラメー タごとの評価結果から 2 つの感性指標間に明らかなトレー ドオフ関係があることを明らかにした。次に, 時々刻々と 変化する評価ドライバの注目する感性指標を識別し, 識別 結果に沿ったパラメータの変更を行うコントローラを前提 に, 感性指標構造の下位部から調整することで, あらゆる 操舵感を向上することができた。本手法は，各々の感性指 標を満足するパラメー夕探索と, その後に感性指標構造を 元に，調整対象を絞り込んだ調整の 2 ステップを踏んでい る。この手法により，これまでは評価ドライバが全ての感 性指標を総合的に着目して行っていた調整パラメー夕を特 定することができて㧍り，また，従来型 EPS 制御系と感性 評価結果を比較した場合, 良好な評価結果を得ることがで きた。

今後, 評価者や対象車種の変更を考えた場合に, 車体挙 動を含め総合的に分析することが重要であると考える。

(平成 21 年 2 月 26 日受付, 平成 21 年 9 月 11 日再受付)

\section{文献}

（1）経済産業省・厚生労働省・文部科学省：「2007 年版ものづくり白書」, 第 1 章第 3 節 4,pp.96-106 (2007)

(2) 安部正人：自動車の運動と制御 [第二版], 山海堂 (2003)

(3) 福山雄一 . 久保田正博 ら : 特開平 8-175416 (1996)

（4）土屋浩司：特開 2003-175838 (2003)

(5) 坂本 清 - 竹原 伸: 特開 2003-137126 (2003)

（6）伊藤英明・樫田美雄ら：「熟練技能中心設計：電動パワーステアリ ング開発におけるイノベーションの創出」, 情処学論, Vol.49, No.4, pp.1581-1593 (2008)

（7）讃井純一郎・乾 正雄：「レパートリー・グリッド発展手法による住 環境評価構造の抽出: 認知心理学に基づく住環境評価に関する研究 (1)」, 日本建築学会計画系論文報告集, Vol.367, pp.15-22 (1986)

（8）豊田秀樹：共分散構造分析 入門編, 朝倉書店 (1998)

（9） N.Cristianini, J. Shawe-Taylor ·大北 剛訳：サポートベクターマシン 入門, 共立出版 (2005)

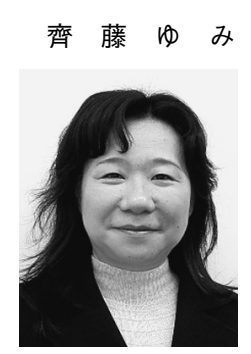

(正員) 1964 年生。1988 年京都大学工学部電気 系卒業。同年立石電機（株）(現オムロン（株）） 入社。知的制御系構築, 音声対話, 知識情報処理 の研究・開発に従事。

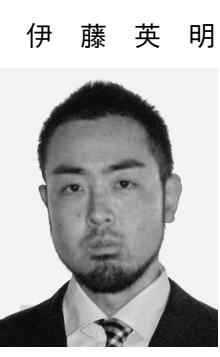

(非会員) 1976 年生。2004 年京都大学大学院情 報学研究科社会情報学専攻博士課程修了。同年才 ムロン (株) 入社。博士 (情報学)。HCI, 知識工 学, マルチエージェントシステムに興味を持つ。 2004 年度電気通信普及財団テレコムシステム技 術賞。情報処理学会, ACM 各会員。

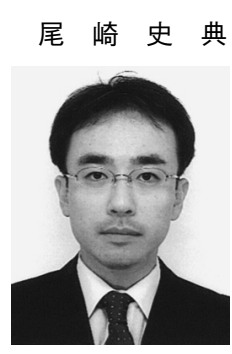

(非会員) 1975 年生。2000 年熊本大学自然科学 研究科数理科学・情報システム専攻博士課程前期 修了。同年才ムロン (株) 入社。半導体製造装置 制御, 電動パワーステアリング制御に関する研究 に従事。2009 年退職。

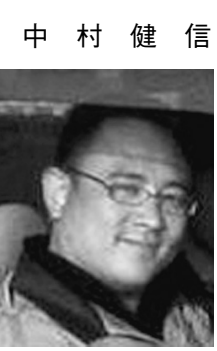

（非会員） 現在，オムロン（株）オートモーティ ブエレクトロニックコンポーネンッカンパニー開 発統括室 EPS 開発部技術企画課にて, 電動パワー ステアリングシステムの開発に従事。

川路 茂 保 (上級会員) 1944 年生。1969 年熊本大学大学院

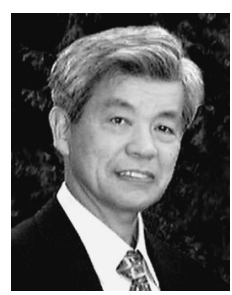
工学研究科電気工学専攻修了。同年同大学工学部 助手。同大学院自然科学研究科教授。計測自動制 御学会 2003 年度学術 (技術賞), SI 部門功績賞。 工学博士 (東京工業大学)。IEEJ プロフェショナ ル, 日本機械学会フェロー, 計測自動制御学会 フェロー。 